\title{
Natural regeneration of Pinus spp. around seed production areas and orchards
}

\section{Magda Santos}

University of Sao Paulo: Universidade de Sao Paulo

Marcio Araujo

IPEF: Instituto de Pesquisas e Estudos Florestais

Paulo Silva ( $\square$ paulohenrique@ipef.br)

Instituto de Pesquisas e Estudos Florestais https://orcid.org/0000-0002-2926-8719

\section{Research Article}

Keywords: Invasion, Exotic species, Regeneration, Establishment potential

Posted Date: March 2nd, 2021

DOI: https://doi.org/10.21203/rs.3.rs-206130/v1

License: (1) This work is licensed under a Creative Commons Attribution 4.0 International License. Read Full License 


\section{Abstract}

This study aims at determining the establishment potential of the main species of the Pinus genus planted in Brazil and broaden the knowledge on the conditions that facilitate the invasion. The density of regenerants neighboring pine stands planted with 35 populations of Pinus spp. (P. caribaea (var. bahamensis and var. caribaea), P. elliottii, P. kesiya, P. merkussi, P. oocarpa, P. patula, P. pseudstrobus, $P$. strobus, $P$. taeda, and $P$. tecunomanii) was evaluated in three locations in the state of São Paulo. The vegetal covers neighboring the pine stands were evaluated regarding native vegetation occupation, open area, and eucalypts plantation. The census of regenerants was conducted up to $100 \mathrm{~m}$ away from the pine stand edges; samples were collected over an area divided into four $25 \mathrm{~m}$-wide transects. In each transect, the regenerants were quantified and classified into three size classes: sprouts $(\leq 0.3 \mathrm{~m})$, seedlings ( $\geq 0.3 \mathrm{~m} \leq 1.0 \mathrm{~m})$, and trees $(>1.0 \mathrm{~m})$. The results indicate that Pinus elliottii is the species with the greatest invasion potential in the studied areas since it adapts to different environments. Areas without established vegetation favored regeneration, indicating the effect of the environment on regeneration occurrence. The number of regenerants increased near the seed source but decreased significantly between 50 and $100 \mathrm{~m}$ away, despite the directional effect of the prevailing winds and the long-distance dispersal capacity of the genus.

\section{Introduction}

Most of the economically important forestry and agronomic crops are grown outside their region of origin and considered exotic species. It becomes, therefore, necessary to know the regeneration potential of the species in different environments since a few species of commercial importance have become invasive, causing problems in different ecosystems (Richardson and Rejmánek 2011; Blackburn et al. 2014).

In Brazil, the exotic forest species belonging to the Eucalyptus and Pinus genera stand out due to the great commercial value and for being important sources of raw material for the industrial forest sector. These species were introduced several times in the country while many introduced populations were maintained as Seeds Production Area (SPA) and Seed Sedlings Orchards (SSO) in experimental stations to serve as seed sources for breeding programs and even commercial planting. Thus, the fact that several species may be found in the same environmental conditions allows studying the regeneration of several species in the same place, as performed for eucalypts (Miolaro et al. 2017).

The species of the Pinus genus were introduced and commercially planted especially in the South and Southeast regions of Brazil (Shimizu et al. 2018) due to good adaptability to environmental conditions and great availability of seeds in SPA and orchards. Paradoxically, these same adaptability characteristics allow the species/genus to become invasive if they are "locally" adapted (AndradeRestrepo et al. 2019).

There is great ecological diversity among the 105 species of the Pinus genus (Richardson and Bond 1991). Of this total, few species were considered as potentially invasive. The genus is registered as an 
invader in several parts of the world, such as New Zealand, Australia, South Africa, Argentina, and Chile (Simberloff et al. 2009). The genus has been registered as a potential invader of open areas, whether degraded or naturally occupied by herbaceous-shrubby vegetation (Zanchetta and Diniz 2006; Simberloff et al. 2009). In Brazil, the described invasions are mainly caused by the two most widespread species of the genus, $P$. taeda and P. elliottii (Ziller and Galvão 2002; Bechara et al. 2013; Brewer et al. 2018; Ramos et al. 2019). An efficient control strategy has been eliminating adult pine trees that function as seed sources and not allowing the next generation to reach maturity ledding to changes in the population structure of pines in protected area (Dechoum et al. 2019). However, other species must be studied in different environments to verify the potential for regeneration and implementation.

This work aims to determine the density of Pinus spp. in three different sites in the State of São Paulo, around homogeneous plantations in the reproductive phase, to identify the factors involved in the regeneration process.

\section{Materials And Methods}

\subsection{Study sites}

The Experimental Station for Forest Sciences (Estação Experimental de Ciências Florestais, EECF) is located in the municipality of Itatinga, SP (23 latitude and $48^{\circ}$ longitude). The area soil is classified as typical moderate Dystrophic Red-Yellow Latosol A, with medium texture (LVAd) (Gonçalves et al. 2012; SANTOS et al. 2018). According to the Köppen classification, the climate is Cwa with humid and hot summer, as well as cold but not very dry winter(Alvares et al. 2013). The average annual temperature is $20.4^{\circ} \mathrm{C}$, with $1,400 \mathrm{~mm}$ average annual precipitation and no water deficit in any season(Gonçalves et al. 2012).

The Anhembi Experimental Station for Forest Sciences (Estação Experimental de Ciências Florestais, EECF) is located in the municipality of Anhembi, SP ( $22^{\circ}$ latitude and $48^{\circ}$ longitude; $500 \mathrm{~m}$ altitude). Soil is predominantly Latosol and Quartzarenic Neosol. The climate is Cwa (Aw), with humid and hot summer, and cold and dry winter, as well as $23^{\circ} \mathrm{C}$ average annual temperature (Alvares et al. 2013). The average annual rainfall is $1,100 \mathrm{~mm}$ but a $20 \mathrm{~mm}$ water deficit is observed in the dry period, between May and August (Ferez et al. 2015). A season characteristic is grazing for grass control, that is, the area is released for cattle after the forest plantations reach arboreal size.

The Ecological Station and State Forest of Angatuba (Estação Ecológica (EEc) e Floresta Estadual (FE) de Angatuba) are located in the municipalities of Angatuba and Guareí, SP ( $23^{\circ}$ latitude; $48^{\circ}$ longitude). Soil is classified as a Hydromorphic Red-yellow Latosol. The climate is classified as Cwa, with $19{ }^{\circ} \mathrm{C}$ and $1215 \mathrm{~mm}$ average annual temperature and rainfall, respectively.

\subsection{Evaluated populations}


A total of 35 populations at least 10 years old were selected to ensure all were of reproductive age. At the Itatinga EECF, the 14 populations over 25 years old (planted between November 1992 and May 1998) selected belonged to the species $P$. taeda, $P$. elliottii, P. caribaea (var. bahamensis and var. caribaea), $P$. patula, $P$. oocarpa, and the hybrids ( $P$. oocarpa $\times P$. caribaea var. hondurensis, $P$ caribaea var. hondurensis $\times P$. caribaea var. caribaea and $P$. caribaea var. hondurensis $\times P$. taeda).

In the EECF of Anhembi, the 17 populations selected were planted between 1977 and 1993, and belong to the species P. merkussi, P. pseudstrobus, P. kesiya, P. oocarpa, P. caribaea (var. hondurensis and var. bahamensis), P. strobus and P. tecunomanii. Additionally, a population of $P$. tecunomanii planted in 2003 was also selected.

In the Angatuba FE, four populations of $P$. elliottii implemented in 1964, 1972, and two in 2007 were selected and are referred to as $P$. elliottii I, II, III, and IV to differentiate among themselves.

\subsection{Data sampling}

Natural regeneration was evaluated over an area of $100 \mathrm{~m}$ away from the edge of the pine stands. To contemplate the entire area established with the regenerants, four $25 \mathrm{~m}$ wide continuous transects measuring between $0-25,25-50,50-75$, and $75-100 \mathrm{~m}$ were placed parallel to the pine stand edge. The census of the regenerants was conducted in each transect and the counted individuals were classified according to their height as sprouts $(\leq 30 \mathrm{~cm})$, seedlings $(\geq 30 \mathrm{~cm} \leq 100 \mathrm{~m})$, and trees $(>100$ $\mathrm{cm}$ ) (Figure 1). The vegetation neighboring the studied population was also evaluated and classified as: eucalyptus, open area, and native vegetation. Due to the area differences for each of the populations, the regenerant counts were converted per hectare.

\subsection{Statistical analysis}

The Anhembi Experimental Station was removed from the statistical analysis because no regenerants were found. The analyzed data were adjusted using the negative binomial distribution because the variance greater than the average for all evaluated characteristics and effects of the model does not allow using the Poisson distribution. Also, the occurrence and abundance of tree seedlings are better described by negative binomial models compared to the Poisson models (Zhang et al. 2012). To adjust the model, analyses were performed for each location, testing the effects of species distance and direction. Additionally, the effects of species and direction over distance were also tested. Confidence intervals (95\%) were estimated to infer the differences in the levels of the effects, that is, differences between species and directions for each regenerant class size (sprouts, seedlings, and trees). The analyses were performed using the software R (R Core Team 2019).

The neighboring vegetation was not statistically analyzed due to the lack of a minimum number of repetitions in each condition. Here, it should be noted that the used data originated from a previously conducted census and not an experiment implemented exclusively for this study. 


\section{Results}

No regenerants were recorded in Anhembi. However, in Angatuba station, an approximate density of 500 sprouts per hectare for population III of Pinus elliotii was observed in the $0-25 \mathrm{~m}$ transect in the eastern direction $(\mathrm{L})$. Nevertheless, because it consisted of only a single record in the data set, the Angatuba site was also excluded from sprout analysis. On the other hand, in Itatinga, sprout density was higher closest to the pine stands (the $0-25 \mathrm{~m}$ transect) and decreased significantly moving away from the edge of the pine stand. The density of sprouts was significantly higher for $P$. elliottii compared to $P$. caribaea in the 0 - $25 \mathrm{~m}$ transect while the highest number of sprouts was mostly observed in the South (S) and West (0) directions. Also, the sprout density of Pinus oocarpa was significantly higher (except for the hybrid $P$. caribaea var. hondurensis $\times$ P. caribaea var. caribaea) in the $25-50 \mathrm{~m}$ transect, but not affected by direction (Figure 2). Further, neither regeneration nor sprouts were observed in the last two (50 - 75 and $75-100 \mathrm{~m})$ transects.

In Angatuba, regenerant seedlings were found only up to $50 \mathrm{~m}$ (first two transects) from the seed source, with no other occurrence in the farther transects (Figure 3A). In Itatinga, the regenerant seedlings were mainly concentrated in the first transect up to $25 \mathrm{~m}$ (Figure 3B). In both sites, the population of regenerant seedlings decreased as the distance from the seed increased. The population II of $P$. elliottii regenerated the most in Angatuba whereas $P$. elliotti was the most regenerant species in Itatinga. Furthermore, the highest number of regenerants were recorded in the East $(L)$ and South $(S)$ directions in the Angatuba and Itatinga sites, respectively (Figure 3).

The regeneration in the tree developmental stage was lower in Itatinga than Angatuba (Figure 4). In Angatuba, the regeneration in the tree phase was similar to the seedling phase, with a predominance of the population II of $P$. elliottii in the East direction.

\section{Discussion}

From the viewpoint of statistical rigor, it was not possible to analyze the effect of the neighboring vegetation, but Pinus spp. regenerants were found in all areas (open areas, as well as eucalyptus and native vegetation-covered areas), the regeneration density in each area corroborates the invasiveness theories regarding both species and environment. In the Anhembi and Itatinga stations, the results of similar observation work regarding eucalypts regenerants indicate that the exposed soil and the absence of predation by ants are fundamental for the successful establishment of sprouts (Silva et al. 2016; Miolaro et al. 2017).

In the Anhembi station, no pine regenerants were found despite the several populations of reproductive age from different species of the genus. This fact is probably related to the evaluated species, livestock management for grass control, and the annual drought. Even though the vegetation does not differ structurally between Anhembi and Itatinga, Anhembi is the only studied place that presents water deficit 
during the dry season. The water deficit of $20 \mathrm{~mm}$ in the region occurs between May and August (Ferez et al. 2015), the same period during which the Pinus spp. seeds are scattered.

In the southeastern and southern regions of Brazil, the reproductive season of $P$. elliottii occurs between March and May (Zanchetta and Pinheiro 2007) while $P$. taeda seeds start to scatter in mid-May and continue until September, with dispersal peaking in July (Jankovski 1996).

Studies on the establishment of eucalypts sprouts under controlled and field conditions highlight the importance of air and soil moisture for the establishment of the sprouts (Silva et al. 2013, 2016), similar to that observed for the Pinus genus in different studies. Furthermore, works in the literature have shown that lack or insufficient humidity in the first year is one of the limiting factors for establishing the $P$. elliottii stands since high mortality rate of the regenerants occur soon after germination, when the humidity is insufficient (Jankovski, 1996). The frequent rains in the southeastern United States after the period of seed dispersal are essential for establishing the natural regeneration of Pinus taeda (Trousdell and Wenger 1963).

Additionally, P. elliotti exhibited a higher occurrence of establishment and is one of the main species of the genus that presents invasion problems (Brewer et al. 2018). But even within the species, the changes observed in the establishment process in the different environments lead to the conclusion that the environment plays a role in this process. Already mentioned in the literature, other species such as $P$. oocarpa have also been shown capable of establishment as regenerant (Zenni and Simberloff 2013; Braga et al. 2014). Although several studied species did not present regenerants (P. kesiya, P. merkussi, $P$. pseudstrobus, $P$. strobus, and $P$. tecunomanii), it is highlighted that the species with the highest occurrence of regenerants are those more widespread in the world and with a greater number of populations evaluated in the study.

The surrounding vegetation is one of the factors strongly influencing the establishment, in addition to the wind. In Angatuba, where open native vegetation (low and scattered trees) is present to the north of the population, a low number of regenerating seedlings (four individuals per hectare) of Pinus elliottii ll was observed, however, a high number of established seedlings (> 800 per ha) up to $50 \mathrm{~m}$ away was observed in the east, the predominant wind direction. (Bognola et al. 2018) evaluated the dispersion of Pinus taeda seeds and concluded that seed density varied significantly among the cardinal points, with the majority being captured in the direction of the predominant wind direction.

Although pine seeds may disperse over a long distance (Benkman 1995) since the seeds are generally small, present wings, and can potentially be carried long distances by the wind, the density of regenerants was higher close to the seed source (up to $50 \mathrm{~m}$ ). Similarly, Jankovski (1996) evaluated the natural regeneration of Pinus spp. and concluded that the density of regenerants decreases with the increasing distance from the pine stand matrix. As the distance increased, more seedlings and trees occurred, but no sprouts. (Pomeroy 1949) reported that more than $85 \%$ of sprouts die because the roots fail to penetrate the soil, as well as grow and develop an efficient root system. A study on Pinus elliottii one year after emergence reported that the sprout bank stabilizes at a young stage (Bourscheid and Reis 2010), 
considered the seedlings in the study. However, adequate conditions are necessary to reach the tree stage.

The sprouts, seedlings and trees were classified and analyzed separately, allowing to differentiate the density of each developmental stage. Analyzing the developmental stages separately is important because it allows proposing management of exotic invaders that is cheaper, more efficient, and less aggressive to the environment being preserved from the invasion (Boursheid and Reis 2010).

The initial establishment stages are the most amenable to economic management, during which the attention to isolated individuals or small groups can be crucial for preventing invasion (Simberloff et al. 2009). Thus, eliminating seedling regenerants is the most appropriate since the high natural mortality of sprouts and their manageable size do not impose major operational challenges. In Argentina, the early control work practiced in experimental plots of natural fields resulted in good recovery of the structure and composition of native species communities (Cuevas and Zalba 2010).

In addition to the management difficulty, with the removal of trees, there is the possibility of worsening invasion after the seedling phase since, as observed in the regenerant trees, seed dispersal may occur. In this phase, regenerants can cause seed rain leading to continuous secondary dispersion in the area and a further worsening of the invasive process (Ramos et al. 2019).

\section{Declarations}

Funding: CAPES Scholarship

Conflicts of interest/Competing interests: Not applicable

Availability of data and material: Not applicable

Code availability: Not applicable

Authors' contributions: Magda Paula dos Santos - field work, data collection and writing the draft; Marcio José de Araujo - writing, data analysis and review; Paulo Henrique Müller da Silva - conceptualization, writing and revision.

\section{Acknowledgments}

We thank the coordinators of the three experimental stations and the Coordination for the Improvement of Higher Education Personnel-CAPES

\section{References}

1. Alvares CA, Stape JL, Sentelhas PC et al (2013) Köppen's climate classification map for Brazil. Meteorol Z 22:711-728. https://doi.org/10.1127/0941-2948/2013/0507 
2. Andrade-Restrepo $M$, Champagnat N, Ferrière $R$ (2019) Local adaptation, dispersal evolution, and the spatial eco-evolutionary dynamics of invasion. Ecol Lett 22:767-777.

https://doi.org/10.1111/ele.13234

3. Bechara FC, Reis A, Boursheid K et al (2013) Reproductive biology and early establishment of Pinus elliottii var. elliottii in Brazilian sandy coastal plain vegetation: implications for biological invasion. Scientia Agricola 70:88-92. https://doi.org/10.1590/S0103-90162013000200005

4. Benkman CW (1995) Wind Dispersal Capacity of Pine Seeds and the Evolution of Different Seed Dispersal Modes in Pines. Oikos 73:221. https://doi.org/10.2307/3545911

5. Blackburn TM, EssI F, Evans T et al (2014) A Unified Classification of Alien Species Based on the Magnitude of their Environmental Impacts. PLoS Biol 12:e1001850. https://doi.org/10.1371/journal.pbio.1001850

6. Bognola IA, Lavoranti OJ, Higa AR et al (2018) Dispersão de sementes, regeneração e rebrota de Pinus taeda no Planalto Norte do Estado de Santa Catarina, Brasil. Pesquisa Florestal Brasileira 38:. https://doi.org/10.4336/2018.pfb.38e201801651

7. Bourscheid K, Reis A (2010) Dinâmica da invasão de Pinus elliottii Engelm. em restinga sob processo de restauração ambiental no Parque Florestal do Rio Vermelho. Biotemas 23:23-30. https://doi.org/10.5007/2175-7925.2010v23n2p23

8. Braga EP, Zenni RD, Hay JD (2014) A new invasive species in South America: Pinus oocarpa Schiede ex Schltdl. Biolnvasions Records 3:207-211. https://doi.org/10.3391/bir.2014.3.3.12

9. Brewer JS, Souza FM, Callaway RM, Durigan G (2018) Impact of invasive slash pine (Pinus elliottii) on groundcover vegetation at home and abroad. Biol Invasions 20:2807-2820. https://doi.org/10.1007/s10530-018-1734-z

10. Cuevas YA, Zalba SM (2010) Recovery of Native Grasslands after Removing Invasive Pines. Restor Ecol 18:711-719. https://doi.org/10.1111/j.1526-100X.2008.00506.x

11. Dechoum M, de S, Giehl, Sühs ELH RB, et al (2019) Citizen engagement in the management of nonnative invasive pines: Does it make a difference? Biol Invasions 21:175-188. https://doi.org/10.1007/s10530-018-1814-0

12. Ferez APC, Campoe OC, Mendes JCT, Stape JL (2015) Silvicultural opportunities for increasing carbon stock in restoration of Atlantic forests in Brazil. For Ecol Manage 350:40-45. https://doi.org/10.1016/j.foreco.2015.04.015

13. Gonçalves JL, de M, Alvares, Gonçalves CA TD, et al (2012) Scientia Forestalis 40:187-201

14. Jankovski T (1996) Estudo de alguns aspectos da regeneração natural induzida em povoamentos de Pinus taeda L. e Pinus elliotti Engelm

15. Miolaro LG, Gonçalves AN, Mendes JCT et al (2017) Spontaneous regeneration of eucalypts from seed production areas. Biol Invasions 19:1733-1737. https://doi.org/10.1007/s10530-017-1397-1

16. Pomeroy K (1949) The Germination and Initial Establishment of Loblolly Pine Under Various Surface Soil Conditions. J Forest 47:541-543. https://doi.org/10.1093/jof/47.7.541 
17. R Core Team (2019) R: A language and environment for statistical computing

18. Ramos M, Magro TC, Couto TZ, Castro TN (2019) Dispersão e impacto de Pinus elliottii Engelm. var. elliottii em área ripária na Floresta Nacional de Capão Bonito-SP Spreading and impact of Pinus elliottii Engelm. var. elliottii on the riparian area in Capão Bonito National Forest-SP state. Ciência Florestal 29:75-85. https://doi.org/10.5902/1980509825789

19. Richardson DM, Bond WJ (1991) Determinants of plant distribution: evidence from pine invasions. Am Nat 137:639-668. https://doi.org/10.1086/285186

20. Richardson DM, Rejmánek M (2011) Trees and shrubs as invasive alien species - a global review. Divers Distrib 17:788-809. https://doi.org/10.1111/j.1472-4642.2011.00782.x

21. SANTOS HG, JACOMINE PKT, ANJOS LHC et al (2018) Sistema Brasileiro de Classificação de Solos, 5. ed. rev. e ampl. Embrapa, Brasília, DF

22. Shimizu J, Aguiar A, Oliveira EB et al (2018) Esforço cooperativo para suporte à silvicultura de pínus no Brasil. In: Embrapa Florestas (ed) $4^{\circ}$ Encontro Brasileiro de Silvicultura. Ribeirão Preto, SP, pp 209-211

23. Silva PHM da, Bouillet JP, Paula RC (2016) Assessing the invasive potential of commercial Eucalyptus species in Brazil: Germination and early establishment. For Ecol Manage 374:129-135. https://doi.org/10.1016/j.foreco.2016.05.007

24. Silva PHM, Miranda AC, Moraes MLT et al (2013) Selecting for rust (Puccinia psidii) resistance in Eucalyptus grandis in São Paulo State, Brazil. For Ecol Manage 303:91-97. https://doi.org/10.1016/j.foreco.2013.04.002

25. Simberloff D, Nuñez MA, Ledgard NJ et al (2009) Spread and impact of introduced conifers in South America: Lessons from other southern hemisphere regions. Austral Ecol 35:489-504. https://doi.org/10.1111/j.1442-9993.2009.02058.x

26. Trousdell K, Wenger K (1963) Some Factors of Climate and Soil Affecting Establishment of Loblolly Pine Stands. Forest Science 9:130-136. https://doi.org/10.1093/forestscience/9.2.130

27. Zanchetta D, Diniz FV (2006) Estudo da contaminação biológica por Pinus spp. em três diferentes áreas na Estação Ecológica de Itirapina (SP, Brasil). Study on Pinus spp. biological contamination in three different areas within the Itirapina Ecological Station (São Paulo, Brazil). Revista do Instituto Florestal 18:1-14

28. Zanchetta D, Pinheiro L de S (2007) Análise Biofísica dos processos envolvidos na invasão biológica de sementes de Pinus elliottii na estação ecológica de Itirapina - SP e alternativas de manejo. Climatologia e Estudos da Paisagem 2:72-90

29. Zenni RD, Simberloff D (2013) Number of source populations as a potential driver of pine invasions in Brazil. Biol Invasions 15:1623-1639. https://doi.org/10.1007/s10530-012-0397-4

30. Zhang X, Lei Y, Cai D, Liu F (2012) Predicting tree recruitment with negative binomial mixture models. For Ecol Manage 270:209-215. https://doi.org/10.1016/j.foreco.2012.01.028

31. Ziller SR, Galvão F (2002) A degradação da estepe gramíneo-lenhosa no Paraná por contaminação biológica de Pinus elliottii e P. taeda. FLORESTA 32:41-47. https://doi.org/10.5380/rf.v32i1.2348 
Figures

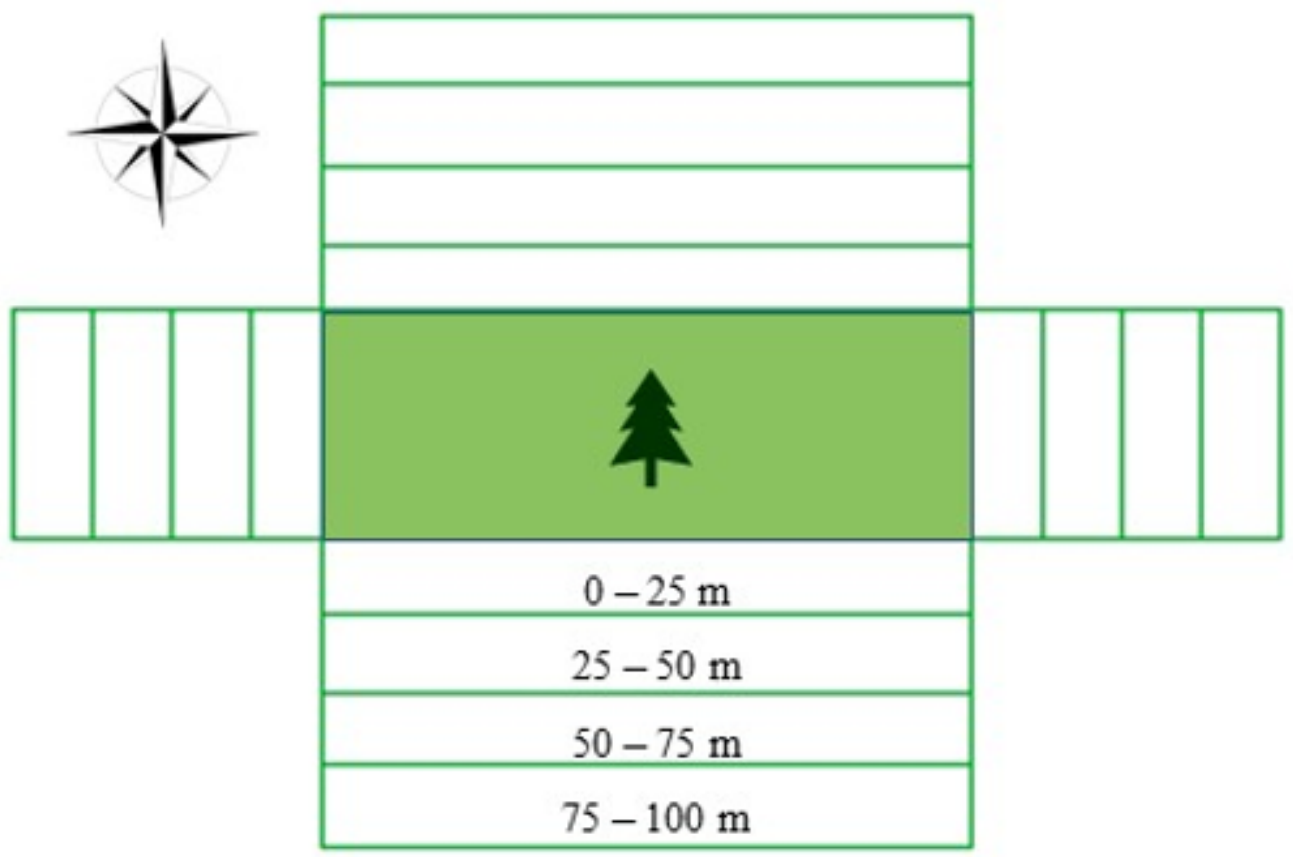

Figure 1

Schematics showing the transect layout regarding the Pinus spp stand. 

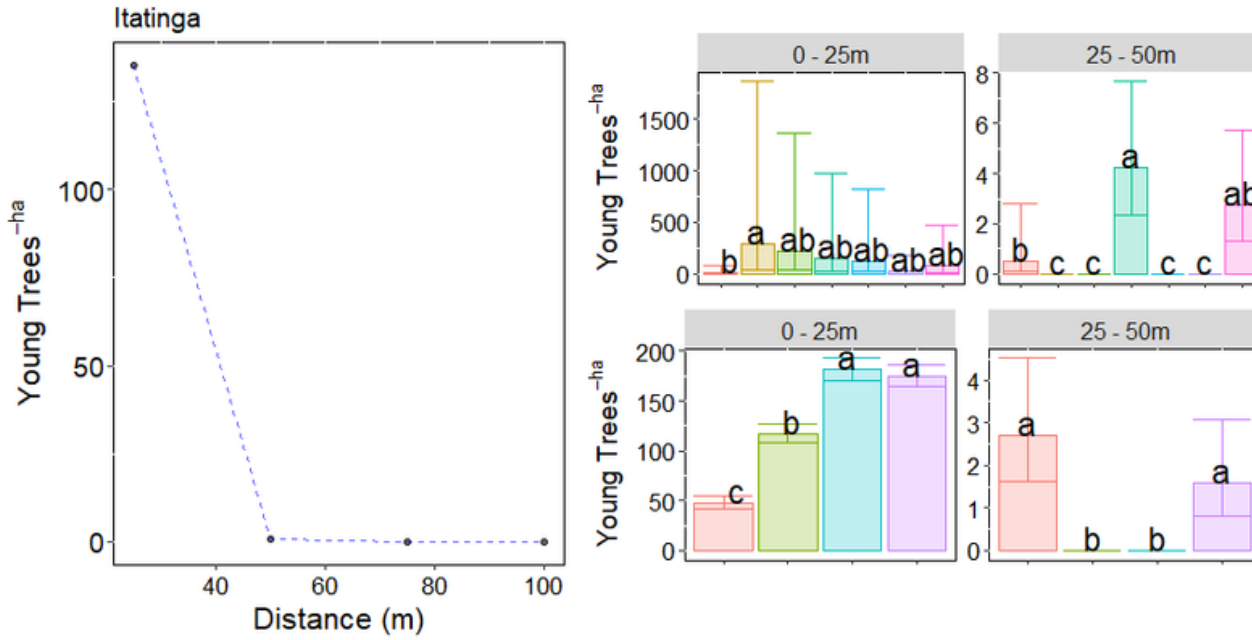

Specie

P. caribaea

P.

P.

P. oocarpa

P. patula

P. taeda

. caribaea var. hondurensis $\times$ P. caribaea var. caribaea

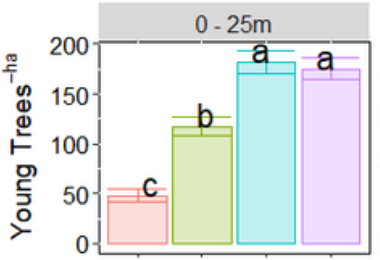

$25.50 m$

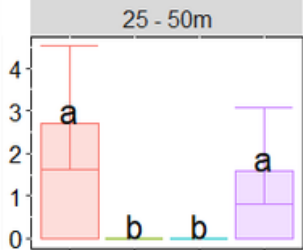

Direction

늘

\section{Figure 2}

Pinus sprout density recorded over the $0-100 \mathrm{~m}$ distance from the plantation stand. The dashed line connects the $0-25,25-50,50-75$, and $75-100 \mathrm{~m}$ transects. The same letters indicate that the density of regenerated sprouts did not differ significantly regarding species and directions at $5 \%$. 

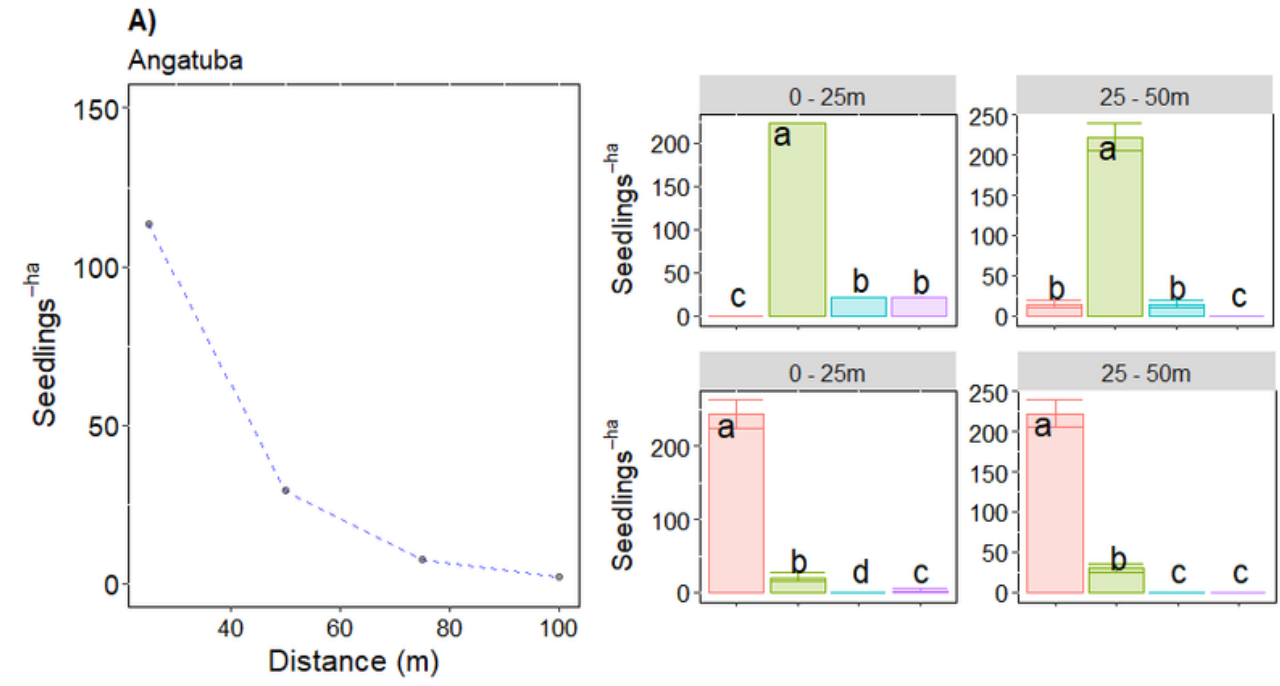

Specie

$\square$ P. elliotti - Population I

P. elliotti - Population II

P. elliotti - Population III

$P$. elliotti - Population IV
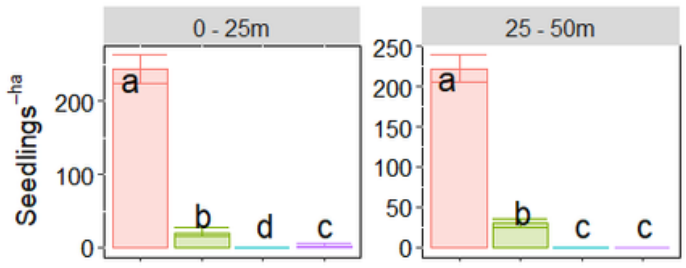

Direction

$\mathrm{L}$
$\mathrm{N}$
$\mathrm{O}$
$\mathrm{S}$

B)
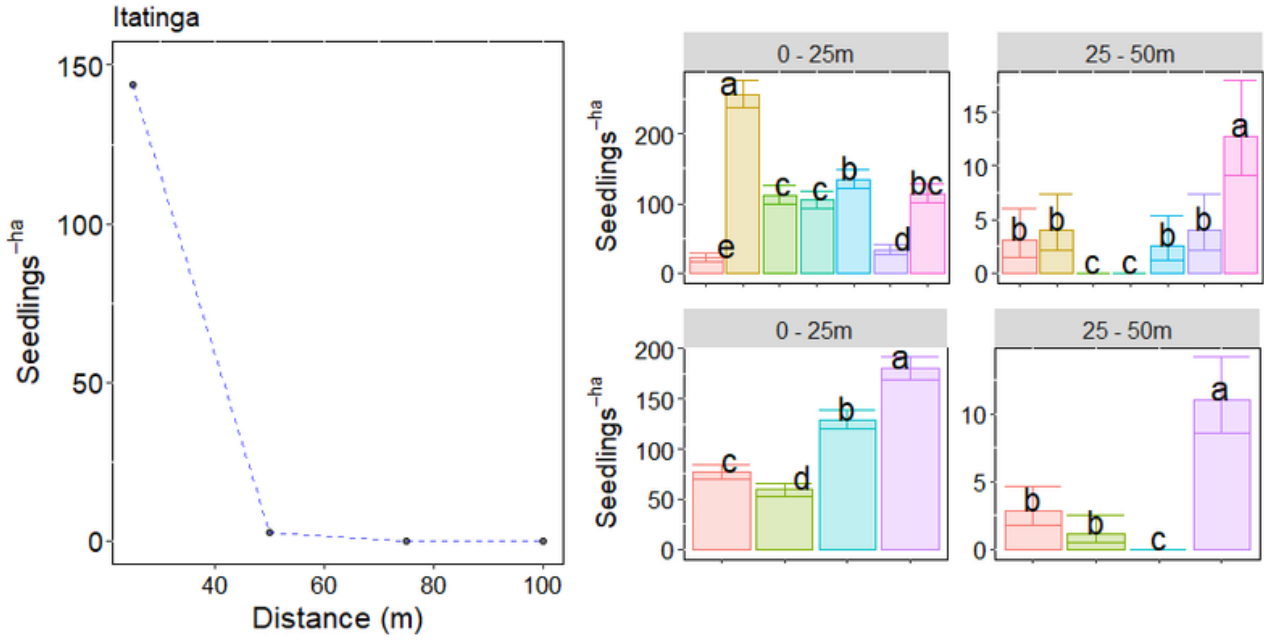

Specie

P. caribaea

$P$. oocarpa $\times P$. caribaea var. hondurensis

P. oocarpa

P. patula

$P$ taeda

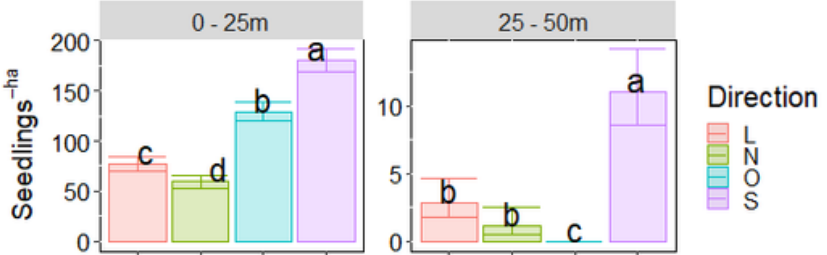

Figure 3

Pinus seedling density over the studied transects $(0$ to $100 \mathrm{~m})$. The dashed line connects the $0-25,25-$ $50,50-75$, and $75-100 \mathrm{~m}$ transects. Same letters mean that the density of regenerant seedlings did not differ significantly regarding species and directions in the Angatuba (A) and Itatinga (B) stations at $5 \%$. 
A)
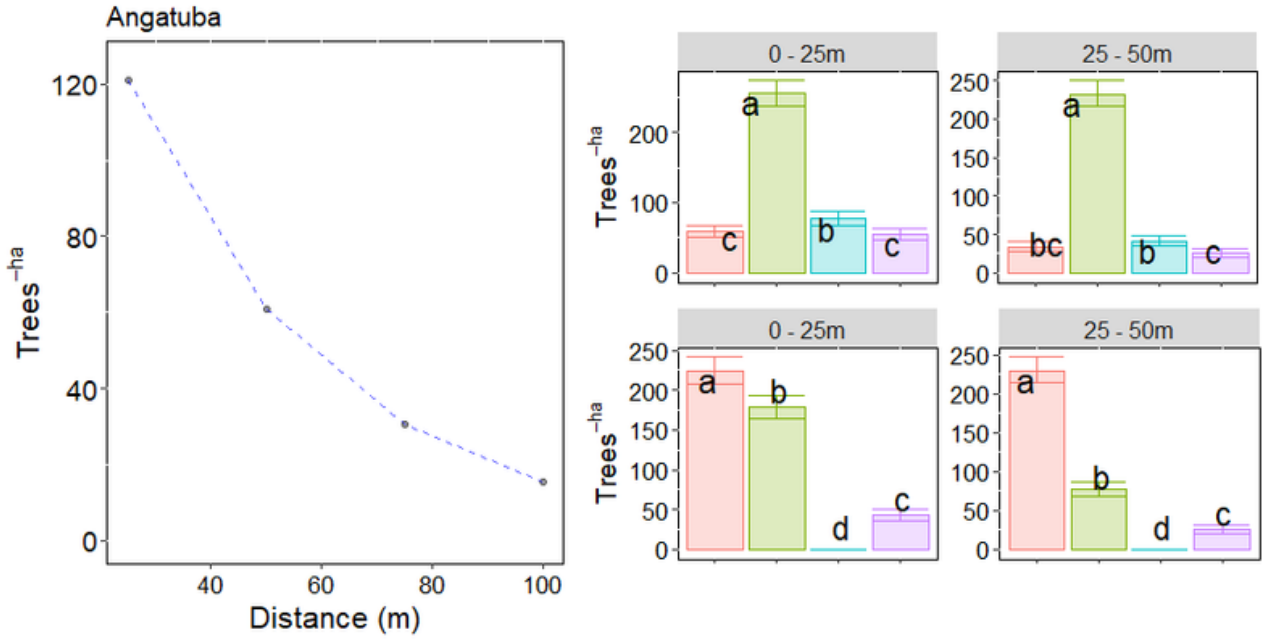

Specie

E P. elliotti - Population I

P. elliotti - Population II

P. elliotti - Population III

P. elliotti - Population IV
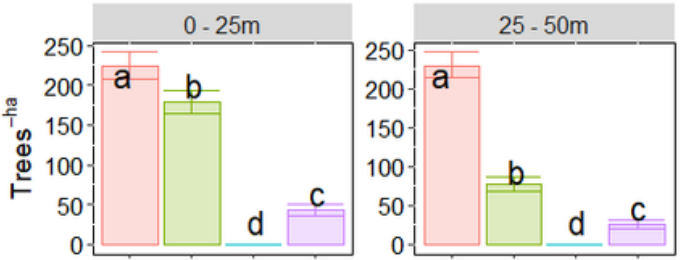

Direction

员

$\stackrel{\mathrm{N}}{\mathrm{O}}$

B)
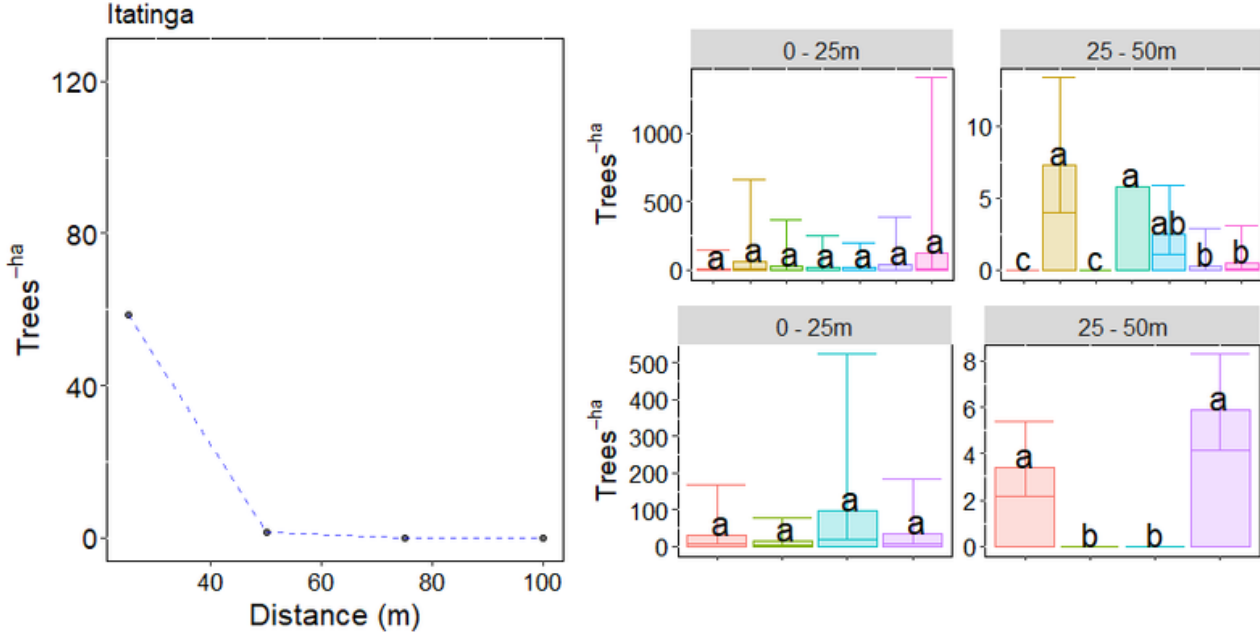

Specie

P. caribaea

P. ellitir $x P$ caribaea var hondurensis

P. oocarpa

P. patula

P. taeda

$P$. caribaea var. hondurensis $\times$ P. caribaea var. caribaea
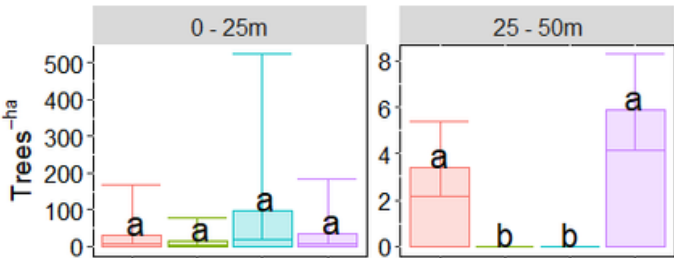

Direction

昵 $\stackrel{\mathrm{N}}{\mathrm{N}}$

$\mathrm{N}$
$\mathrm{O}$
$\mathrm{S}$

\section{Figure 4}

